This item is the archived peer-reviewed author-version of:

Parenting and family structure after divorce : are they related?

\title{
Reference:
}

Bastaits Kim, Mortelmans Dimitri.- Parenting and family structure after divorce : are they related?

Journal of divorce and remarriage - ISSN 1540-4811 - 58:7(2017), p. 542-558

Full text (Publisher's DOI): https://doi.org/10.1080/10502556.2017.1345200

To cite this reference: https://hdl.handle.net/10067/1470570151162165141 


\section{Parenting and Family Structure After Divorce: Are They Related?}

Parenting might differ according to the family structure. As the family process paradigm states (Cavanagh, 2008), changes in family structure can lead to alterations in family roles, like the parental role. In the past, most research concerning parenting and family structure has concentrated on the comparison of parenting by married and divorced parents, preferable even mothers (for overview, see Hetherington and Stanley-Hagen, 2002). Still, as stated by Amato (2000), divorce is a process that leads to other family transitions. Divorce and its consequent transitions might influence the family structure and (temporarily) lead to a more chaotic home environment, where everybody has to settle in their new role. Consequently, a diversity in family structures after divorce that could affect parenting, exists. Recently, this diversity of post-divorce family structures and their influence on parenting has gained more interest. Still, previous studies on parenting after divorce lack the inclusion of all family structures, focussing either on repartnering comparing stepfamilies to singleparent families and intact families (e.g., Hetherington, 2006; Gibson-Davis, 2008; Thomson, Hanson, \& McLanahan, 1994) or on comparing various custodial arrangements (e.g., Campana, Henderson, Stolberg, \& Schum, 2008; Lee, 2002). Both could, however, reinforce each other in the way they affect parenting after divorce.

Therefore, this study investigate parenting after divorce in a variety of family structures, including information on repartnering of both parents as well as the current custodial arrangement of the child, as this combination is rarely studied. This study contributes to the literature by taking a dyadic approach, investigating relationships between maternal and paternal family structure and both maternal and paternal parenting, as previous research has mainly concentrated on maternal parenting (e.g., Benson, Buehler \& Gerard, 2008; Lengua, Wolchik, Sandler \& West, 2000; Wood, Repetti, \& Roesch, 2004), although attention for paternal parenting has recently increased (e.g., 
Bastaits, Ponnet \& Mortelmans, 2014; Booth, Scott \& King, 2010). Moreover, this study uses child reports on parenting, whereas previous studies were mainly based on parent reports of parenting (e.g. Capaldi, Pears, Kerr \& Owen, 2008; Fagan \& Palkovits, 2011; Hohmann-Marriott, 2011; Ryan, Kalil \& Ziol-Guest, 2008)

To this end, we analyze multi-actor data from the Divorce in Flanders ${ }^{1}$ (DiF) dataset. The DiF dataset is particularly well suited for research on divorce, as Belgium (of which Flanders is the Dutch speaking part) plays a leading role in the rising divorce rates in Europe (Eurostat, 2012). The dataset also offers specific advantages for this research. First, since 2006, Belgium has a legal preference for joint physical custody (Sodermans, Matthijs \& Swicegood, 2013). Therefore, the DiF dataset contains a substantial number of respondents living in joint physical custody arrangements. Second, the multiactor design of the DiF dataset makes it possible to adapt a dyadic approach. Third, despite an overrepresentation of divorced partners, still-married partners were questioned as well, thus allowing comparisons between still-married parents and divorced parents in various family constellations.

\section{Theory on Parenting}

Effective parenting is defined as being a supportive parent who also sets boundaries (Baumrind, 2013). These two aspects are in line with Baumrind's theory on parenting $(1991,2013)$, which argues that parenting consists of two dimensions: support and control. Support refers to the affection, warmth and love that children receive from their parents. Control refers to confrontive control, which is goal-oriented and sets boundaries and limits. Both support and control are needed in order to obtain the most optimal development of children. As children develop in interaction with their parents and their socialization runs through this interaction, parenting should be considered as one of the most important predictors of children's well-being and development. Previous research has

\footnotetext{
${ }^{1}$ Flanders is the Dutch-speaking part of Belgium.
} 
also indicated that children benefit from parenting with high levels of support and control (e.g. Bastaits \& Mortelmans, 2014; Baumrind, 1991).

\section{Parenting and Post-Divorce Family Structure}

The style of parenting mothers and fathers adopt, also depends on the family structure in which children are raised. A main line of research on parenting and family structure concentrates on the differences between parenting in married and divorced families. Previous research has established that married and divorced parents differ with regard to the amount of support and control they provide for their children. Results from a study by Vandoorne and colleagues (2000) indicate that divorced parents are less supportive and less controlling than still-married parents are. A literature overview by Hetherington and Stanley-Hagen (2002) further indicates that divorced parents are less involved than still-married parents are.

Still, as divorce should be considered as a process that sets in motion other family transitions, due to repartnering and custodial arrangements (Amato, 2000), one should look behind the divide married/divorced. As previous studies investigating parenting and post-divorce family structures mainly focused on either the impact of repartnering (e.g., Hetherington, 2006; Gibson-Davis, 2008; Thomson, Hanson, \& McLanahan, 1994) or the custodial arrangements (e.g., Campana, Henderson, Stolberg, \& Schum, 2008; Lee, 2002), we would like to investigate both, for mothers as well as fathers. Therefore, we start from the parental resource theory (Thomson et al., 1994). According to this theory, parents can provide two resources: money and time. Money allows parents to provide for their children whereas time gives them the opportunity to support and control their children. Other researchers have also stressed the importance of the time parents and children spend together plays in parenting (King, 2006; King \& Sobolewski, 2006; Pasley \& Braver, 2004; Peters \& Ehrenberg, 2008). If parents and children spend less time together, the level of parental support and control might decrease as well. After a parental divorce, the time parents spend with their children 
changes, due to the custodial arrangement as well as the possible repartnering of one or both parents.

On the one hand, literature on parenting and post-divorce family structure has concentrate on the influence of the custodial arrangement on parenting. Starting from the parental resource theory, it is clear that the custodial arrangement after divorce interferes with the resource of time. As one becomes a non-residential parent, the time spend with the child(ren) is significantly reduced, which might lead to a decline in support and control. Previous studies have indeed indicated that nonresidential parents (in many cases, fathers) provide lower levels of support and control, whereas residential parents (in many cases, mothers) provide higher levels of support and control (Bastaits, Ponnet, \& Mortelmans, 2012; Hetherington \& Stanley-Hagen, 1999; Vandoorne et al., 2000). With regard to joint physical custody, a less studied custodial arrangement, previous findings indicate that parents (both mothers and fathers) in joint physical custody are as involved as residential parents and more involved (i.e. more supportive and controlling) than non-residential parents (Bastaits, Ponnet \& Mortelmans, 2012; Bastaits, Van Peer, and Mortelmans, 2013). In a study of the paired parenting styles of mothers and fathers in various custody arrangements, Campana and colleagues (2008) found that mothers with sole custody and mothers in joint custody arrangements are more likely to be both supportive and controlling (i.e. an authoritative parenting style), as compared to mothers without physical custody, who are more likely to be only supportive (i.e. a permissive parenting style). For fathers, results revealed that, although most divorced fathers do not have physical sole-custody, these fathers are more likely to be authoritative. Non-residential fathers and fathers in joint custody arrangements are more likely to be permissive.

On the other hand, research on parenting and post-divorce family structure has focused on the repartnering of one or both parents. Although this seems less straightforward than for the custodial arrangement, having a new partner also interferes with the parental resource of time. Parents need to divide their time between their child and their partner (and as such take up two roles: the parental 
and the partner role), as both the child and the new partner compete for the parent's attention (Adamson \& Pasley, 2006; Thomson, Mosley, Hanson \& McLanahan, 2001). The parent will have to divide his or her attention between the child and the new partner, thus leading to a decrease in the time available to dedicate to the child, which can decrease a parent's level of involvement. According to a study by Pryor (2004), adolescents who have experienced several parental partner transitions report lower levels of parental support and control. Thomson and colleagues (2001) report that mothers who have repartnered after divorce are less controlling. Other scholars have found comparable results, revealing that remarried parents provide less support and control (Henderson \& Taylor, 1999). Still, if a new partner enter the family, he (or she) will bring resources of his own, either financial or as help and support for the formerly single parent. This could have a positive effect on the parenting of repartnered mothers and fathers (Hetherington, 2006), as they will have more time to spend with the child instead of working or doing all household chores by themselves. A study by Vandoorne and colleagues (2000) sustains this principle, as it reveals that parental support for a child is higher when the parent is living with a new partner, even if the child does not live with this parent.

\section{Current Study}

Based on these previous results and the parental resource theory, we hypothesize that parents who live in a family structure where they spend less time with their child will be less supportive and less controlling. So, non-residential parents or residential parents who live together with a new partner will be less supportive and less controlling than still married parents, single residential parents or parents in joint physical custody (hypothesis 1). Still, it might be the case that only non-residential parents will be less supportive and controlling than parents in other family types as living with a new partner has the upside of having access to new resources that might increase the time spend with the child and therefore also the support and control (hypothesis 2). Based on previous findings, we do not expect gender differences between maternal and paternal parenting.

Met opmerkingen [RC1]: Before moving on to Methods we ask all authors to provide a brief discussion of their own context. This is based on a belief that who you are and how you are involved with the topic and study will influence the presentation. We want readers the topic and study will influence the presentation. We want readers evaluation of the study and to have greater confidence in what they are about to read. Toward that end, please tell us your relationship to this inquiry. Who are you? What is your interest in this topic? What is your investment in this project? What are your intentions?

Met opmerkingen [BK2R1]: We hope that this added description of the research centre of both authors as well as the research interests of both authors provides the context in which this study has taken place. 
This study fits well within the research team and previous work of both authors. Both authors are part of the Research Centre for Longitudinal and Life Course Studies (CLLS). CLLS is known in the international academic community as a research centre covering a large number of topics in the fields of social demography, family sociology and sociology of health and illness. Within these fields, the life course perspective and the element of time and timing is central, both theoretically and empirically. For many decades, divorce and repartnering is one of the major research streams in the centre. The first author started as a pre-doctoral researcher on the 'Divorce in Flanders - DiF' project, were she was involved in the data collection process. Meanwhile, she started her PhD “Divorced... with children. Parenting of divorced fathers" (Bastaits, 2014), which she successfully defended in 2014. As a post-doctoral researcher, she is part of the European project "Families and Societies", of which this study is a result. Throughout her research career, her interests have always been parenting, divorce, family structure \& transitions and children's well-being. She has published several peer-reviewed articles on these topics in both national and international journals. The second author initiated the research group CLLS in 2004 after the end of the Panel Study of Belgian Households. He continued the existing research stream on divorce and applied successfully as promotor-spokesman for the research infrastructure Divorce in Flanders. Next to the data collection of the Divorce in Flanders project, Mortelmans has done research on the economic consequences of divorce (Jansen, Mortelmans, Snoeckx, 2009), repartnering (Pasteels, Mortelmans, 2017), poverty and lone parenthood (Mortelmans, Defever, 2017) and personality and divorce (Boertien, Mortelmans, 2017). A driving force behind this research is the exploration of processes of social exclusion due to life course events. Divorce patterns are social determined and we want to understand these to gain insights in their adverse effects, both for adults and for their children.

\section{Method}


Our analyses are based on a subsample of the multi-actor 'Divorce in Flanders - DiF' dataset. The DiF-dataset was collected within a SBO-project ${ }^{2}$ with a team that consist of four of the five Flemish universities as well as the Research Section of the Flemish Government. Although Belgium has one of the most liberal divorce laws as well as a high divorce rates, recent scientific data and insights were lacking (Mortelmans \& Pasteels, 2011). Therefore, this SBO-project was granted. The DiF-team constructed both the design (multi-actor and multi-method) as well as the questionnaires (based on a thorough literature review) of this study. Afterwards, data were collected in collaboration with a data collection agency. Nevertheless, the DiF-team did the follow up of the data collection and transformed the collected data into ready-to-use datasets. Since then, the DiF-dataset is used in various national as well as international studies and publications. More information on the DiF dataset and procedures can be found in Pasteels et al. (2011).

The complete DiF dataset contains information on parents, children aged 10 years or older, grandparents, and stepparents. After the DiF-team got their request for a sample based on the National Register approved by the Belgian Privacy Commission, addresses of the parents (1/3 of whom were still married and $2 / 3$ of whom were divorced) were randomly selected from this National Register. They had to have the Belgian nationality and had to be married between 1971 and 2008 and only divorced once. These parents were the primary actors and, if they participated, they provided the contact information for the secondary actors (children, grandparents, and stepparents). For each parental reference marriage, one child of at least 10 years old(in case of multiple children, this child was randomly selected), one maternal grandparent, one paternal grandparent, and all possible stepparents were questioned. Parents and children were questioned with a computerassisted personal interview (CAPI), whereas grandparents and possible stepparents completed written questionnaires. Data were collected between October 2009 and December 2010. Response of the primary respondents was $42.2 \%(\mathrm{~N}=6470)$, a response rate that is close to other European

\footnotetext{
${ }^{2}$ An SBO-project is a project granted by the government and should have either an economic or a social
} value for stakeholders.
Met opmerkingen [RC3]: Plese share some more background on this dataset (e.g., it's originas, who collects it, etc.).

Met opmerkingen [BK4R3]: We added this paragraph that (in short) gives the background of the DiF-data. In the previous section, we also mentioned that both authors were involved in the DiF project. Hopefully, this provided a better insight in the context of the DiF-data.

Met opmerkingen [RC5]: Please use active voice so the subject of the sentence performs the action expressed by the verb in the sentence. We ask our authors to use active voice to express their actions as the instrument clearly and to help readers focus on who did what in the study.

Met opmerkingen [BK6R5]: Using the active voice in this sentence, would in our opinion result in a 'weirdly' constructed sentence. In Belgium, data from the National Register are not freely available, and we had to put in a request for them to select the addresses. To make this clear, we added this part of the sentence: "After the DiF-team got their request for a sample based on the National Register approved by the Belgian Privacy Commission,...". The selection of addresses, however, happens at the National Register, as these are highly secured. 
multi-actor surveys (Arranz Becker et al., 2012; Dykstra et al., 2005) We used a dyadic subsample of 618 parents (still-married or divorced) and residential children between the ages of 10 and 18 years (following the example of McLeod, Weisz \& Wood, 2007) to conduct our analyses. Children had to be in contact with both parents, as this study focuses on the parenting of both parents. Parents reported about the family structure and the background characteristics of both parents and children, whereas children reported about the parenting of both mothers and fathers.

\section{Measures}

Family structure. The independent variable family structure is based on two other variables: the presence of a new partner in the household of the divorced mother or father, as well as the custodial arrangement. The former was derived from information taken from the household grid by checking for the presence of a partner in the household if the parent was divorced. The latter variable was measured according to a double custodial calendar, in which the parent indicated the nights that the child stayed with him or her and the nights the child stayed with the former partner in a regular month. Following other research on custodial arrangements (Melli, 1999; Smyth \& Moloney, 2008), we defined children who stayed with their mothers between $33 \%$ and $66 \%$ of the nights and with their fathers between $33 \%$ and $66 \%$ of the nights as living in joint physical custody arrangements. If children stayed with their mothers for more than $66 \%$ of the nights and with their father for less than $33 \%$ of the nights, the mother was defined as the residential parent and the father as the nonresidential parent. If children stayed with their fathers for more than $66 \%$ of the nights and with their mother for less than $33 \%$ of the nights, the father was defined as the residential parent and the mother as the non-residential parent. Combining the information of the household grid with that of the custodial calendar generated the following categories of family structure: still-married parents ( $\mathrm{n}$ $=224)$, single residential mothers $(n=116)$, residential mothers living with new partners $(n=109)$, parents with joint physical custody $(n=138)$, single residential fathers $(n=13)$ and residential fathers living with new partners $(n=16)$. 
Parenting. Parental support and parental control were measured using the Parenting Style Inventory II (Darling \& Toyokawa, 1997). This PSI-II was included in the DiF-questionnaire of the children. Children completed both subscales of this scale for their mothers and fathers separately. Each subscale consisted of five items that children were asked to rate along a five-point Likert scale ranging from 1 (strongly disagree) to 5 (strongly agree). For the subscale of support, confirmatory factor analysis revealed a single factor behind the five items, loading sufficiently high on a latent factor for both mothers and father (factor loadings for mothers ranged from 0.47 to 0.83 ; factor loadings for fathers ranged from 0.41 to 0.81). Exemplary items are "I can count on my mother/father to help me out if I have a problem," and "My mother-father and I do things that are fun together." After twice freeing a covariance between similarly worded items in the latent construct for mothers and fathers, various fit indices indicated an adequate fit (RMSEA=0.06, $\mathrm{CFI}=0.95, \mathrm{SRMR}=0.04)$. Composite reliability was 0.80 for both mothers and fathers. The confirmatory factor analysis for the subscale control revealed that three out of five items loaded on one latent factor, with sufficiently high factor loadings for both mothers and fathers (factor loadings for mothers ranged from 0.46 to 0.94 ; factor loadings for fathers ranged from 0.60 to 0.93 ). Exemplary items for the subscale of control are "If I don't behave myself, my mother/father will punish me," and "My mother/father points out ways that I could do better." After freeing a covariance between a similarly worded item in the latent construct for mothers and fathers, it showed a good fit (RMSEA=0.05, CFI=0.98, SRMR=0.03). Composite reliability was 0.70 for mothers and 0.76 for fathers.

Control variables. We incorporated background characteristics of the child, the mother, and the father into our analyses. We included age $(M=14.29$ and $S D=2.54)$ and gender $(49.52 \%$ boys and $50.48 \%$ girls $)$ as child characteristics. For mothers, we included age $(M=42.77$ and $S D=4.13)$ and educational level (13.30\% lower secondary education or lower education, $41.67 \%$ higher secondary education, $45.03 \%$ higher education). For fathers, we also included age ( $M=44.39$ and SD $=4.24)$ and educational level (18.23 lower secondary education or lower education, 46.13 higher secondary education, 35.65\% higher education).
Met opmerkingen [RC7]: Is this Inventory part of the dataset or dod you import it? Please clarify.

Met opmerkingen [BK8R7]: This scale was included in the child questionnaire of the DiF study and as such in the dataset. We did not import it. To clarify this, we added the sentence: "This PSI-II was included in the Dif-questionnaire of the children." 


\section{Analytic Strategy}

When taking a dyadic approach, it is important to organize the analytic sample in a dyadic way. We therefore structured the raw data from our subsample as dyads, such that each data line contains information on both the child and the parent. Our process of restructuring the data in this way is based on the dyadic data-organization technique proposed by Kenny, Kashy and Cook (2006) The dyadic organization of our analytic sample allows us to estimate the effects of both actors (e.g., maternal family structure on maternal parenting) and partners (e.g., maternal family structure on paternal parenting).

This dyadic model was estimated using structural equation modeling (SEM). A preliminary test indicated that our subsample deviated from the normality assumption. In testing our model, therefore, we used MLR estimation, which is robust for non-normal data (Brown, 2006). Missing data were treated differently for dependent and independent variables. For the dependent variable, fullinformation maximum likelihood (FIML) was used to estimate the models. This estimation method prescribed a specific treatment for missing data on maternal and paternal parenting, involving the imputation of missing values on these dependent variables based on information from the variance/covariance matrix. Imputation was used for independent variables, as a substantial amount of information (more than $8 \%$ ) was missing for a specific variable (the new partner of the mother and new partner of the father). For these cases, information from the other parent was used to impute information for the parent with missing data. We were able to take advantage of this property of multi-actor data only if both parents had participated in the DiF survey. The technique reduced the extent of missing data substantially (from $10.4 \%$ to $0.5 \%$ for information on the new partner of the mother; from $13.9 \%$ to $2.5 \%$ for information on the new partner of the father). In all other cases, missing data on independent variables were treated with listwise deletion. Statistical analyses were performed in Mplus 6 (Muthén \& Muthén, 2010). Each model shows standardized coefficients. 


\section{Measurement Model}

The measurement model for all latent variables is shown in Figure 1. As expected, factor loadings were sufficiently high ( $\geq 0.41)$. Various fit indices indicated a good fit (RMSEA $=0.05, C F I=0.94$, SRMR $=0.04 ;$ Brown, 2006). With regard to correlations between the latent constructs, maternal support was significantly and positively correlated with both paternal support and paternal control. This result is due to the use of the same subscale for maternal and paternal parenting.

\section{Figure 1: Measurement model for latent constructs}

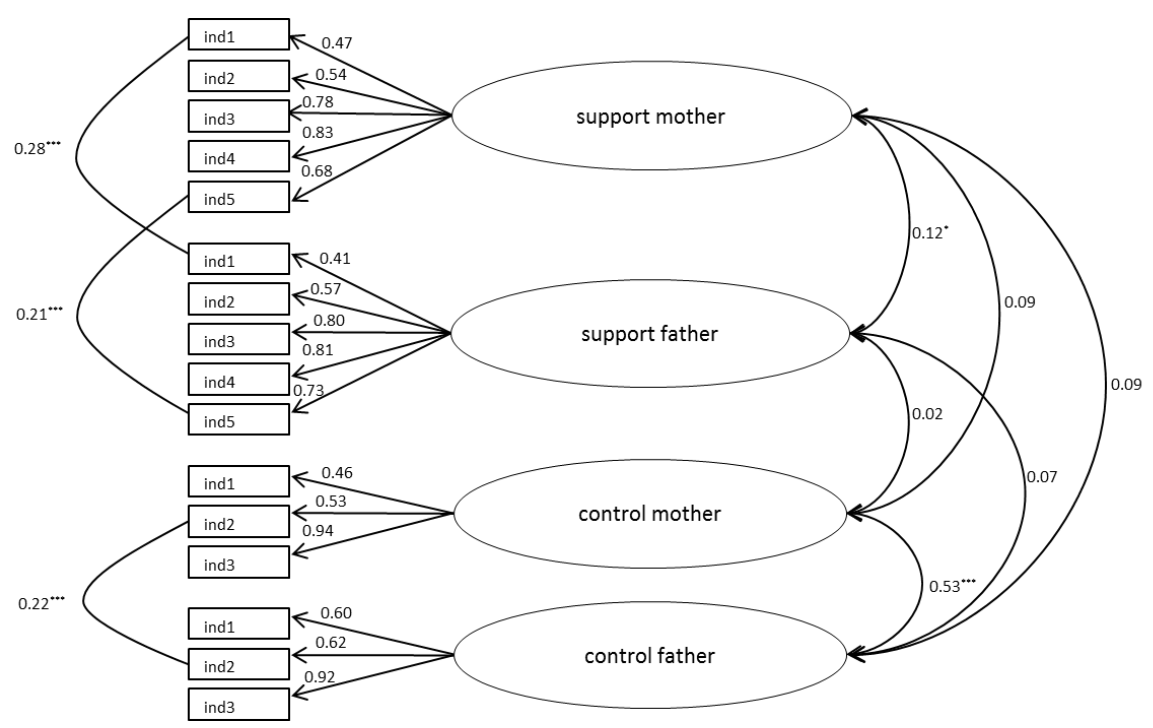

\section{Structural Regression Model}

The estimated structural equation model is shown in Figure 2. Both actor effects (e.g., the impact of living with the mother on maternal parenting) and partner effects (e.g., the impact of living with the mother on paternal parenting) are displayed. Still-married parents constitute the reference 
category. All results should therefore be interpreted relative to the group of still-married parents. All paths are estimated controlling for the background characteristics of parents and children, as mentioned above, but only significant paths are shown. The overall model reveals a good fit (RMSEA $=0.04, \mathrm{CFI}=0.93, \mathrm{SRMR}=0.03)$.

*insert Figure $2^{*}$

With regard to actor effects (solid arrows), results indicate that single, residential mothers are less likely to be controlling than are mothers who are still married. The absence of this effect for residential mothers with new partners indicates that the parenting of these mothers does not differ significantly from that of their still-married counterparts. With regard to fathers, the results reveal that residential fathers provide significantly higher levels of support than still-married fathers do, regardless of whether they are repartnered. According to the results for joint physical custody, mothers in joint physical custody are less controlling than are still-married mothers. No significant differences were found for fathers in joint physical custody.

With regard to partner effects (dotted arrows), the results indicate that divorced fathers are significantly less controlling than are their still-married counterparts if the mothers are residential. They are also less supportive than their still-married counterparts are if the residential mother is single. The results for residential fathers clearly indicate that mothers are significantly less supportive than their still-married counterparts, regardless of the presence of a new partner in the father's household.

\section{Discussion}

After a parental divorce, children live in variety of family structures, due to the custodial arrangement as well as the possible repartnering of both parents. This might affect how children are raised within those family types. Previous research has indeed profoundly investigated these plurality of family structures and its impact on children's well-being and or the parent-child relationship 
(Campana, Henderson, Stolberg, \& Schum, 2008; Hetherington, 2006; Gibson-Davis, 2008; Lee, 2002; Nielsen, 2014). Still, studies either focused on the repartnering of one or both parents or on the custodial arrangement. Moreover, maternal parenting is the primary focus of these studies, largely ignoring paternal parenting. Therefore, this study estimated a dyadic SEM model with both actor and partner effects to investigate how maternal and paternal parenting after divorce differ according to family structure, taking into account the repartnering of both parents as well as the custodial arrangement.

The results of this study provide evidence for our second hypothesis. According to our findings, non-residential parents provide less support and less control (the latter applying only to nonresidential fathers and mothers in joint physical custody). This is in line with parental resource theory (Thomson et al., 1994), which identifies time as a vital resource that allows parents to be involved with their children. For residential parents, the only difference appears to be a decline in maternal control on the part of single residential mothers. No such decline is evident for residential mothers with new partners. Our results identify residential fathers as a relatively specific group, exhibiting higher levels of support than still-married fathers do, regardless of their partner status. This might be due to the small number of residential fathers in our sample. Nevertheless, the results for mothers provide additional evidence for the assumption that new partners bring along their own resources, thereby having a positive influence on the parenting of divorced parents (Hetherington, 2006). They provide less support for the parental resource theory, which argues that the presence of a new partner lead parents to spend less time with their children and therefore to be less involved. Our results reveal a very specific relationship between repartnered mothers and the parenting of fathers. Whereas non-residential fathers provided less support than married fathers did if the residential mother was single, this was not the case if the residential mother was living with a new partner (i.e., the child had a stepparent). This relatively surprising result might be due to potential jealousy and rivalry between the biological father and the stepfather (Ganong, Coleman \& Hans, 2006). It could be that biological fathers feel threatened by the presence and the role of stepfathers, leading them to 
compensate by being as supportive as still-married fathers are. Another possible explanation might be that mothers want to spend more time with their new partner, leaving less time to be involved with the child, in line with the parental resource theory (Thomson et al., 1994). Consequently, the father needs to be more involved with the child, since the level of involvement of the mother might have dropped.

Overall, our study reveals two particularly striking results. First, being the non-residential parent of the child after divorce is negatively related to parental involvement. Second, the absence of a partner can lead to less involved parenting. These findings are in line with previous studies (e.g., Bastaits et al., 2014; King, 2006; Vandoorne et al., 2000), although these studies focus largely on either custodial arrangements or the presence of a new partner. Moreover, our results provide evidence supporting the use of an dyadic SEM model to examine family structures and parenting, as they reveal inter-relationships between the family structure of the mother and paternal parenting and vice versa. These findings are quite consistent with family system theory (Cox \& Paley, 1997; Minuchin, 1974), which states that family members and their behaviors are mutually and necessarily interdependent. Families are thus complex, multilateral, and integrated structures that extend beyond the household. The actions of family members affect other family members and their actions. Even after divorce, the former partners remain linked through the parenting of their children. Current families are thus less defined by their location (e.g., living in the same household) than they are by their actions or, in other words, by "doing family" (Morgan, 2011). This does not only have consequences for future family studies, as they should start from a family perspective rather than an individual perspective, but also for family therapist, social workers,... as they should also take into account the linkages that still remain between ex-partners when they are parents. Especially with children and the way their parent are involved, it is important to adopt a family perspective and start to work from there, rather than an individual perspective, looking only at the child or at one side of the family. 
It is important to note several limitations to this study. First, our analyses are based on crosssectional data, thus eliminating the possibility of drawing any causal conclusions from our findings. As such, we provide a snapshot of maternal and paternal parenting at a certain point in time. Given that parenting is dynamic rather than static, it can be influenced by various family transitions. Future research should therefore focus on how parenting changes over time, especially for parents and children who have experienced one or more family transitions. Moreover, given that families undergo transitions over time (Amato, 2000), it would be even more interesting to investigate the interplay between changing family structures and changes in parenting.

A second limitation of this study has to do with the limited availability of information on the repartnering of both mothers and fathers when organizing the multi-actor DiF data in a dyadic data structure. For example, the data contained no information on the duration of new partnerships for either mothers or fathers. It could nevertheless be assumed that mechanisms related to both role conflict and new resources are at play when investigating the impact of a new partner on parenting. These mechanisms are likely to depend on the duration of the relationship. It might be safe to assume that a parent experiences role conflict in the beginning of the new relationship, as the parent, stepparent, and child must grow accustomed to their new roles. This could be accompanied by a decrease in parental involvement, as the new relationship requires the parent to focus on both the children and the new partner. As the duration of the relationship increases, parents, stepparents, and children are likely to settle into their new roles, such that the additional resources brought by the new partner/stepparent have a positive impact on parental involvement. Future research should thus also control for the duration of the partnership. It should also investigate differences in parenting in both simple stepfamilies (in which only a stepparent enters the family) and complex stepfamilies (in which stepparents bring along own children, such that the family includes stepsiblings and/or half siblings, in addition to a stepparent). Living in a complex stepfamily is likely to increase the risk of role conflict. In contrast, the members of simple stepfamilies are likely to settle into their new roles more easily. 
A third limitation relates to residential fathers. As these groups (both single residential fathers and residential father living together with a new partner) were relatively small compared to the other groups, results should be interpreted with caution. Future research should investigate more in these specific types of fathers and their parenting compared to non-residential fathers or fathers in joint custody.

A final limitation of our study is that the sample from the DiF dataset allowed us to investigate only separation and the subsequent family structures of married parents. Given the current increase in the number of non-married parents in Western Europe, future research should also examine the separation of never-divorced parents and the ways in which their family structures affect parenting. In conclusion, the results of this study indicate that not all divorced mothers and fathers are less supportive and controlling than their still-married counterparts are. When investigating parenting after divorce, it is important to consider account both custodial arrangements and the possible repartnering of both the mother and the father. Moreover, researchers should focus on both mothers and fathers, as we have learned from using the dyadic SEM model with both actor and partner effects. Even after divorce, parents remain linked to each other, as the child they have together deserves to be raised in an optimal manner by both parents. 


\section{References}

Adamson, K., \& Pasley, K. (2006). Coparenting following divorce and relationship dissolution. In M. A.

Fine, \& J. H. Harvey (Eds.) Handbook of divorce and relationship dissolution (241-261). Mahwah,

NJ: Lawrence Erlbaum Associates.

Amato, P.R (2000). The consequences of divorce for adults and children. Journal of Marriage and Family, 62, 1269-1287.

Arránz Becker, O., Brüderl, J., Buhr, P., Castiglioni, L., Fuß, D., Ludwig, V., Schröder, J. \& Schumann, N. (2012). The German Family Panel: Study Design and Cumulated Field Report (Waves 1 to 3). Pairfam Technical paper 01. Germany: Pairfam.

[http://www.pairfam.de/fileadmin/user_upload/redakteur/publis/Dokumentation/TechnicalPape rs/TP01_Field-Report_pairfam4.0.pdf].

Bastaits, K. (2014). Divorced... with children. Parenting of divorced fathers. Antwerp: University of Antwerp.

Bastaits, K., Ponnet, K., \& Mortelmans, D. (2012). Parenting of divorced fathers and the association with children's self-esteem. Journal of Youth and Adolescence, 41, 1643-1656.

Bastaits, K., Ponnet, K., \& Mortelmans, D. (2014). Do divorced fathers matter? The impact of parenting styles of divorced fathers on the well-being of the child. Journal of Divorce and Remarriage, 55, 1-27.

Bastaits, K., Van Peer, C., \& Mortelmans, D. (2013). Ouderlijke opvoedingsstijlen na echtscheiding In M. Corijn en C. Van Peer (Eds.), Gezinstransities in Vlaanderen (309-330). Brussel: Studiedienst van de Vlaamse Regering, SVR-Studie 2.

Baumrind, D. (1991). The influence of parenting style on adolescent competence and substance use. The Journal of Early Adolescence, 11, 56-95. 
Baumrind, D. (2013). Authoritative parenting revisited: History and current status. In .E. Larzelere,

A.S. Morris, \& A.W. Harrist (Eds.) Authoritative parenting. Synthesizing nurturance and discipline for optimal child development (11-34). Washington: American Psychological Association.

Benson, M.J., Buehler, C. \& Gerard, J.M. (2008). Interparental hostility and early adolescent problems behavior: spillover via maternal acceptance, harshness, inconsistency and intrusiveness. The Journal of Early Adolescence, 28, 428-454.

Booth, A., Scott M.E. \& King, V. (2010). Father residence and adolescent problem behaviour: are youth always better off in two-parent families? Journal of Family Issues, 31, 585-605.

Boertien, D., \& Mortelmans, D. (2017). Does the relationship between personality and divorce change over time? A cross-country comparison of marriage cohorts. Acta Sociologica. doi:10.1177/0001699317709048

Brown, T.A. (2006). Confirmatory factor analysis for applied research. New York: The Guilford Press.

Campana, K.L., Henderson, S., Stolberg, A.L. \& Schum, L. (2008). Paired maternal and paternal parenting styles, child custody and children's emotional adjustment to divorce. Journal of Divorce and Remarriage, 48, 1-20.

Capaldi, D.M., Pears, K.C., Kerr, D.C.R. \& Owen, L.D. (2008). Intergenerational and partner influences on fathers' negative discipline. Journal of Abnormal Child Psychology, 36, 347-358.

Cox, M. J., \& Paley, B. (1997). Families as systems. Annual Review of Psychology, 48, 243-267.

Darling, N. \& Toyokawa, T. (1997), Construction and Validation of the Parenting Style Inventory II (PSIII). Pennsylvania: The Pennsylvania State University, department of human development and family studies.

Dykstra, P.A., Kalmijn, M., Knijn, T.C.M., Komter, A.E., Liefbroer, A.C. \& Mulder, C.H. (2005). Codebook of the Netherlands Kinship Panel Study, a multi-actor, multi-method panel study on 
solidarity in family relationships, Wave 1. NKPS Working Paper No. 4. The Hague: Netherlands Interdisciplinary Demographic Institute. [http://www.nkps.nl/NKPSEN/nkps.htm]

Eurostat. (2012). Divorces per 1000 persons. From

[http://epp.eurostat.ec.europa.eu/portal/page/portal/population/data/main_tables].

Fagan,J. \& Palkovitz, R. (2011). Coparenting and relationship quality effects on father engagement: Variations by residence, romance. Journal of Marriage and Family, 73, 637 - 653.

Ganong, L., Coleman, M., \& Hans, J. (2006). Divorce as prelude to stepfamily living and the consequences of redivorce. In M. A. Fine, \& J. H. Harvey (Eds.) Handbook of divorce and relationship dissolution (409-434). Mahwah, NJ: Lawrence Erlbaum Associates.

Gibson-Davis, C.M. (2008). Family structure effects on maternal and paternal parenting in lowincome families. Journal of Marriage and Family, 70, 452-465.

Henderson, S. H., \& Taylor, L. C. (1999). Parent-adolescent relationships in nonstep-, simple step- and complex stepfamilies, Monographs of the Society for Research in Child Development, 64, 79-100.

Hetherington, E. M. (2006). The influence of conflict, marital problem solving and parenting on children's adjustment in nondivorced, divorced and remarried families. In A. Clarke-Stewart, \& J. Dunn (Eds.), Families count. Effects on child and adolescent development (203-237). Cambridge, NY: Cambridge University Press.

Hetherington, E.M. \& Stanley-Hagen, M.M. (1999). The adjustment of children with divorced parents: a risk and resiliency perspective. Journal of Child Psychiatry, 40, 129-140.

Hetherington, E.M. \& Stanley-Hagen, M. (2002). Parenting in divorced and remarried families. In

M.H. Bornstein (Ed.), Handbook of parenting, volume 3: being and becoming a parent (287-315). Mahwah, NJ: Lawrence Erlbaum Associates Publishers. 
Hohman-Mariott, B. , 2011. Coparenting and father involvement in married and unmarried coresident couples. Journal of Marriage and Family, 73, 296 - 309.

Jansen, M., Mortelmans, D., \& Snoeckx, L. (2009). Repartnering and (Re)employment: Strategies to Cope With the Economic Consequences of Partnership Dissolution. Journal of Marriage and Family, 71(5), 1271-1293. doi:10.1111/j.1741-3737.2009.00668.x

Kenny, D.A., Kashy, D.A., and Cook, W.L. (2006). Dyadic Data Analysis. New York, NY: The Guilford Press.

King, V. (2006). The antecedents and consequences of adolescents' relationships with stepfathers and nonresident fathers. Journal of Marriage and Family, 68, 910-928.

King, V. \& Sobolewski, J.M. (2006). Nonresident fathers' contributions to adolescent well-being. Journal of Marriage and Family, 68, 537-557.

Lansford, J. E. (2009). Parental divorce and children's adjustment. Perspectives on Psychological Science, 4, 140-152.

Lee, M.Y. (2002). A model of children's post-divorce behavioral adjustment in maternal- and dualresidence arrangements. Journal of Family Issues, 23, 672-697.

Lemieux, M. (10 en 11 mei 2005). La survie du couple parental. Paper gepresenteerd op het Colloqium "Regards sur la diversité de la famille: mieux comprendre pour mieux soutenir" Québec Conseil de la Famille et de l’Enfance du Québec.

Lengua, L.J., Wolchik, S.A., Sandler, I.N. \& West, S.G. (2000). The additive and interactive effects of parenting and temperament in predicting adjustment problems of children of divorce. Journal of Clinical Child Psychology, 29, 232-244. 
Marquet, J. (2007). Contractualisering van de huwelijksbanden: van huwen uit liefde tot scheiden uit verloren liefde. In R. Bulckens, M.T. Casman, D. Mortelmans \& C. Simaÿs (Eds.), Families in beweging: een gezinsbeleid op maat? (40-45). Brussel: Luc Pire Uitgeverij

McLeod, B.D., Weisz, J.R. \& Wood, J.J. (2007). Examining the association between parenting and childhood depression: a meta-analysis. Clinical Psychology Review, 27, 986-1003.

Melli, M. S. (1999). Guideline review: child support and time sharing by parents. Family Law Quarterly, 33, 219-234.

Minuchin, S. (1974). Families and Family therapy. Cambridge, MA: Harvard University Press. Morgan, D.J.H. (2011). Locating 'family practices'. Sociological Research Online, 16, 1-9.

Mortelmans, D., \& Defever, C. (2017). Income trajectories of lone parents after divorce. A view with Belgian register data. In L. Bernardi \& D. Mortelmans (Eds.), Lone Parenthood in a Life Course Perspective (forthcoming). Berlin: Springer.

Mortelmans, D. \& Pasteels, I. (2011). Scheiding in Vlaanderen: ontstaan en inhoud van de multiactorstudie naar relatiebreuken in Vlaanderen. In D. Mortelmans, I. Pasteels, P. Bracke, K. Matthijs, J. Van Bavel \& C. Van Peer (Eds.), Scheiding in Vlaanderen (11-25). Leuven: Acco.

Muthén, L.K. and Muthén, B.O. (2010). Mplus User's Guide. Sixth Edition. Los Angeles, CA: Muthén \& Muthén.

Nielsen, L. (2014). Shared physical custody: summary of 40 studies on outcomes for children. Journal of Divorce and Remarriage, 55, 613-635.

Pasley, K. \& Braver, S.L. (2004). Measuring father involvement in divorced, non-resident fathers. In R.D. Day \& M.E. Lamb (Eds.), Conceptualizing and measuring father involvement (217-240). Mahwah, NJ: Lawrence Erlbaum Associates. 
Pasteels I., Mortelmans, D., Bracke, P., Matthijs, K., Van Bavel, J. \& Van Peer, C. (2011) Divorce in

Flanders. Multi-actordesign, sampling design and response rates. Antwerp: University of Antwerp.

Pasteels, I., \& Mortelmans, D. (2017). The socioeconomic determinants of repartnering after divorce or separation in Belgium. Demographic Research, 36, 1785-1812.

doi:10.4054/DemRes.2017.36.58

Peters, B., \& Ehrenberg, M. F. (2008). The influence of parental separation and divorce on fatherchild relationships. Journal of Divorce and Remarriage, 49, 78-109.

Pryor, J. (2004). Parenting in reconstructed and surrogate families. In M. Hoghughi \& N. Long (Eds.), Handbook of parenting: Theory and research for practice (110-129). London: Sage.

Ryan, R.M., Kalil, A. \& Ziol-Guest, K.M. (2008). Longitudinal patterns of non-resident fathers' involvement: the role of resources and relations. Journal of Marriage and Family, 70, 962-977.

Smyth, B., \& Moloney, L. (2008). Changes in patterns of post-separation parenting over time: a brief review. Journal of Family Studies, 14, 7-22.

Sodermans, A. K., Matthijs, K., \& Swicegood, G. (2013). Characteristics of joint physical custody families in Flanders. Demographic Research, 28, 821-848.

Thomson, E., Hanson, T. L., \& McLanahan, S. S. (1994). Family structure and child well-being: Economic resources vs. parental behaviors. Social Forces, 73, 221-242.

Thomson, E., Mosley, J., Hanson, T.L. \& McLanahan, S.S. (2001). Remarriage, cohabitation and changes in mother behavior. Journal of Marriage and Family, 63, 370-380.

Vandoorne, J., Decaluwe, L. \& Vandemeulebroecke, L. (2000). Het gezin. In H. De Witte, J. Hooghe \& L. Walgrave (Eds.), Jongeren in Vlaanderen: gemeten en geteld (59-79). Leuven: Universitaire Pers Leuven. 
Wood, J.J., Repetti, R.L. \& Roesch, S.C. (2004). Divorce and children's adjustment problems at home and school: the role of depressive/withdrawn parenting. Child Psychology and Human Development, 35, 121-142. 


\section{Acknowledgement}

The research leading to these results has received funding from the European Union's Seventh Framework Programme (FP7/2007-2013) under grant agreement no. 320116 for the research project FamiliesAndSocieties.

Abstract: Children are raised in various family structures after a parental divorce. Currently, research including both repartnering and the custodial arrangement when investigating parenting, is scarce and mainly proceeds from a maternal perspective, ignoring potential partner effects. Consequently, we investigate differences in parenting after divorce according to family structure (repartnering and custodial arrangement), analyzing a dyadic subsample of the multi-actor Divorce in Flanders dataset (616 children and parents) using a structural equation model. We conclude that living with a partner has a positive effect on parenting, whereas not living with the child has a relatively negative effect on parenting, regardless of the parental gender.

Keywords: Family structure, parenting, mothers, fathers, children, divorce 